U.S. Department of the Interior

U.S. Geological Survey

\title{
Volcano-Hazard Zonation for San Vicente Volcano, El Salvador
}

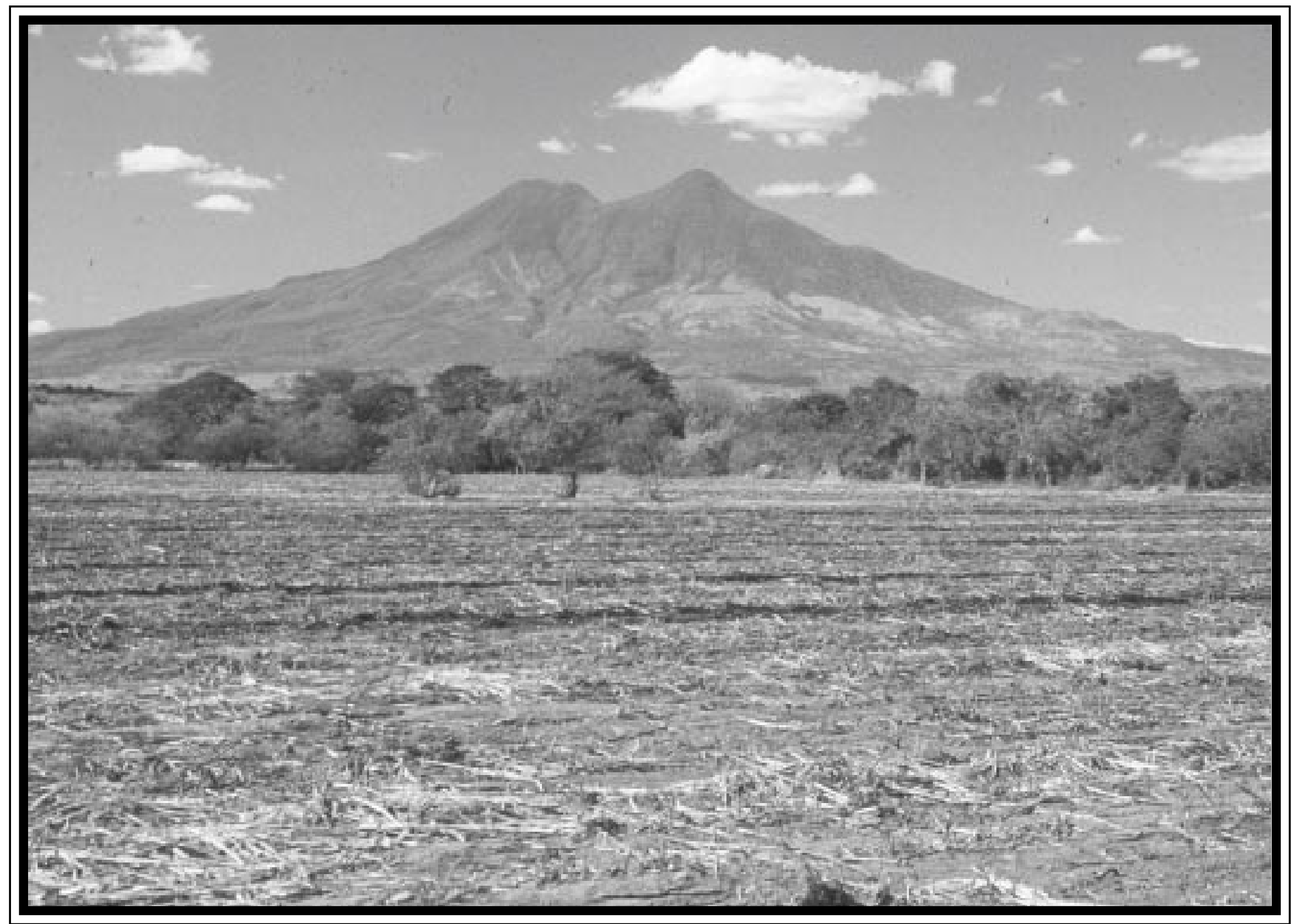

Open-File Report 01-367

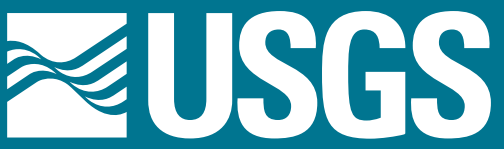




\section{Cover photograph}

San Vicente volcano viewed from the southeast. Note the dual cones of the volcano. The La Carbonera complex is located to the west of the volcano and the youngest cone is on the right, indicating that the focus of volcanic activity has migrated roughly eastward with time. (Photograph by J.J. Major, U.S. Geological Survey). 


\section{Volcano-Hazard Zonation for San Vicente Volcano, El Salvador}

By J.J. Major, S.P. Schilling, C.R Pullinger, C.D. Escobar, and M.M. Howell

\section{U.S. GEOLOGICAL SURVEY}

Open-File Report 01-367 


\section{U.S. DEPARTMENT OF THE INTERIOR \\ Gale Norton, Secretary}

U.S. GEOLOGICAL SURVEY

Charles G. Groat, Director

This report is preliminary and has not been reviewed for conformity with U.S. Geological Survey editorial standards. Any use of trade, product, or firm names is for descriptive purposes only and does not imply endorsement by the U.S. Government.

For additional information write to:

\section{Scientist-in-Charge}

U.S. Geological Survey

1300 SE Cardinal Court, Bldg. 10

Vancouver, WA 98683

(360) $993-8900$

FAX: (360) 993-8980
Copies of this report can be purchased from:

U.S. Geological Survey

Information Services

P.0. Box 25286

Denver, CO 80225

(303) 202-4210 


\section{CONTENTS}

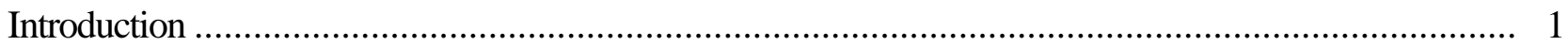

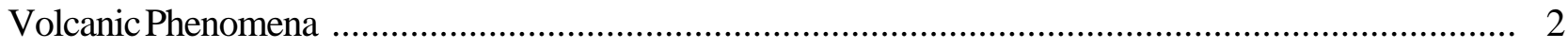

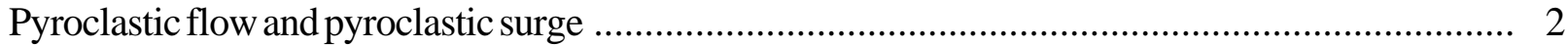

Lava flows and lava domes .................................................................................. 4

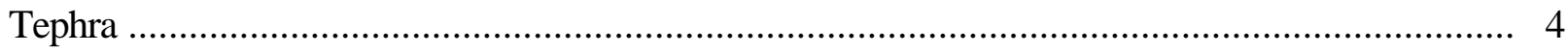

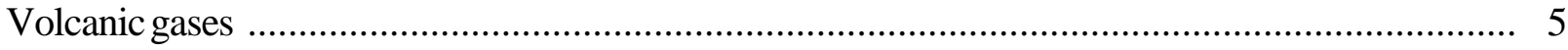

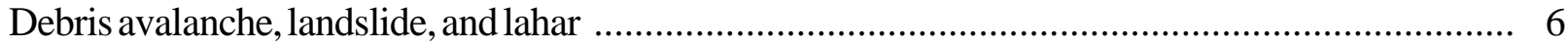

Past Events at San Vicente Volcano ...................................................................................

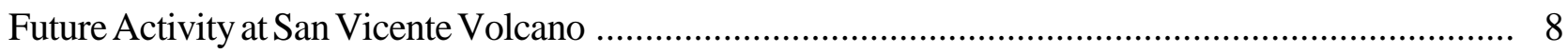

Events at Other Volcanoes Can Affect the San Vicente Region ............................................... 9

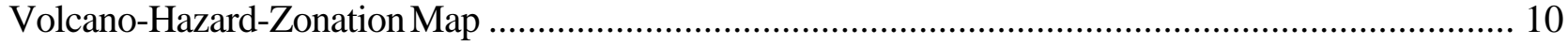

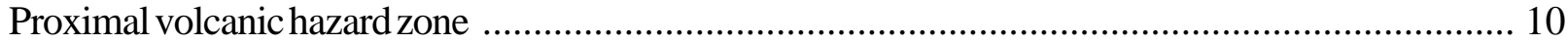

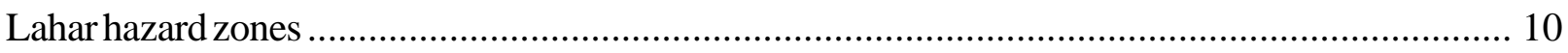

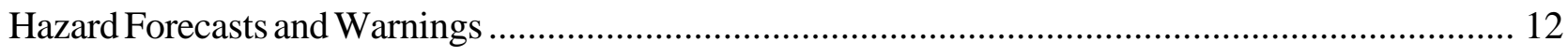

Protecting Communities and Citizens from Volcano-Related Hazards ............................................ 12

References

13

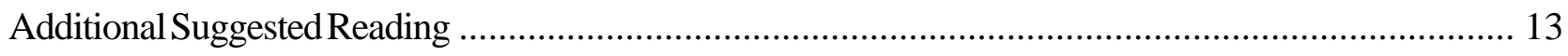

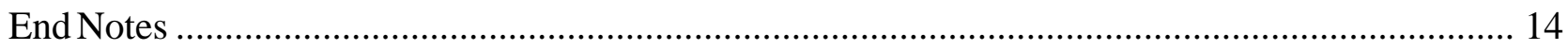

PLATE [In pocket]

1. Volcano-hazard zonation for San Vicente Volcano, El Salvador.

\section{FIGURES}

1. Location of major cities and significant Quaternary volcanoes in El Salvador ........................... 2

2. Simplified sketch showing hazardous events associated with a volcano like San Vicente ............... 3 



\title{
Volcano-Hazard Zonation for San Vicente Volcano, El Salvador
}

\author{
By J.J. Major, S.P. Schilling, C.R Pullinger'1, C.D. Escobar' ${ }^{1}$, M.M. Howell
}

\section{INTRODUCTION}

San Vicente volcano, also known as

Chichontepec, is one of many volcanoes along the volcanic arc in El Salvador (figure 1). This composite volcano, located about 50 kilometers east of the capital city San Salvador, has a volume of about 130 cubic kilometers, rises to an altitude of about 2180 meters, and towers above major communities such as San Vicente, Tepetitan, Guadalupe, Zacatecoluca, and Tecoluca. In addition to the larger communities that surround the volcano, several smaller communities and coffee plantations are located on or around the flanks of the volcano, and major transportation routes are located near the lowermost southern and eastern flanks of the volcano. The population density and proximity around San Vicente volcano, as well as the proximity of major transportation routes, increase the risk that even small landslides or eruptions, likely to occur again, can have serious societal consequences.

The eruptive history of San Vicente volcano is not well known, and there is no definitive record of historical eruptive activity [1] (numerals in brackets refer to end notes in the report). The last significant eruption occurred more than 1700 years ago, and perhaps long before permanent human habitation of the area. Nevertheless, this volcano has a very long history of repeated, and sometimes violent, eruptions, and at least once a large section of the volcano collapsed in a massive landslide. The oldest rocks associated with a volcanic center at San Vicente are more than 2 million years old. The volcano is composed of remnants of multiple eruptive centers that have migrated roughly eastward with time. Future eruptions of this volcano will pose substantial risk to surrounding communities.

Volcanic eruptions are not the only events that present a risk to local communities. Another concern is a landslide and associated debris flow (a watery flow of mud, rock, and debris--also known as a lahar) that could occur during periods of no volcanic activity. An event of this type occurred in 1998 at Casita volcano in Nicaragua when extremely heavy rainfall from Hurricane Mitch triggered a landslide that moved down slope and transformed into a rapidly moving debris flow that destroyed two villages and killed more than 2000 people. Historical landslides up to a few hundred thousand cubic meters in volume have been triggered at San Vicente volcano by torrential rainstorms and earthquakes, and some have transformed into debris flows that have inundated villages down stream [1]. For example, a debris flow in 1934 on the north side of San Vicente destroyed the village of Tepetitan. Destructive rainfall- and earthquake-triggered landslides and debris flows on or near San Salvador volcano, west of San Vicente, in September 1982 and January 2001 demonstrate that such mass movements in $\mathrm{El}$ Salvador have also been lethal.

This report describes the kinds of hazardous events that occur at volcanoes in general and the

1 Servicio Nacionale de Estudios Terretoriales, Ave. Roosevelt y 55 Ave. Norte, Torre El Salvador (IPSFA) 
kinds of hazardous geologic events that have occurred at San Vicente volcano in the past. The accompanying volcano-hazards-zonation map shows areas that are likely to be at risk when hazardous events occur again.

\section{VOLCANIC PHENOMENA}

Volcanoes pose a variety of geologic hazards-both during eruptions and in the absence of eruptive activity (figure 2). Although it has been several thousand years since the last significant eruption of San Vicente volcano, many of the hazardous events depicted in figure 2 have occurred at San Vicente in the past and will likely occur again. Most of these events are caused by the eruption of molten rock, or magma, but some, like debris avalanches (landslides) and lahars, can occur without eruptive activity. The nature and scale of eruptive activity depends in part on the size and type of volcano, the composition of the magma, and on interactions between magma and water.

\section{Pyroclastic flow and pyroclastic surge}

Explosive eruptions can produce mixtures of hot gases and volcanic rock particles that are denser than air. Such dense mixtures behave like a fluid, stay close to the ground, and flow downslope away from the volcano. If the mixture is made up mostly of rock particles, then it has a high density and its path will be confined to topographically low areas, much as topography will control the flow of water. This type of dense flow is called a pyroclastic

flow. However, if the mixture is made up mostly of gas with a small proportion of rock fragments, then it will have a lower density and its path will be less controlled by topography. This type of gas-rich mixture is called a pyroclastic surge. Pyroclastic flows and surges also produce ash clouds that can rise thousands of meters into the air, drift downwind, and transport ash for tens of kilometers or more from a volcano.

Pyroclastic flows and surges often occur together, and both are exceedingly hazardous.

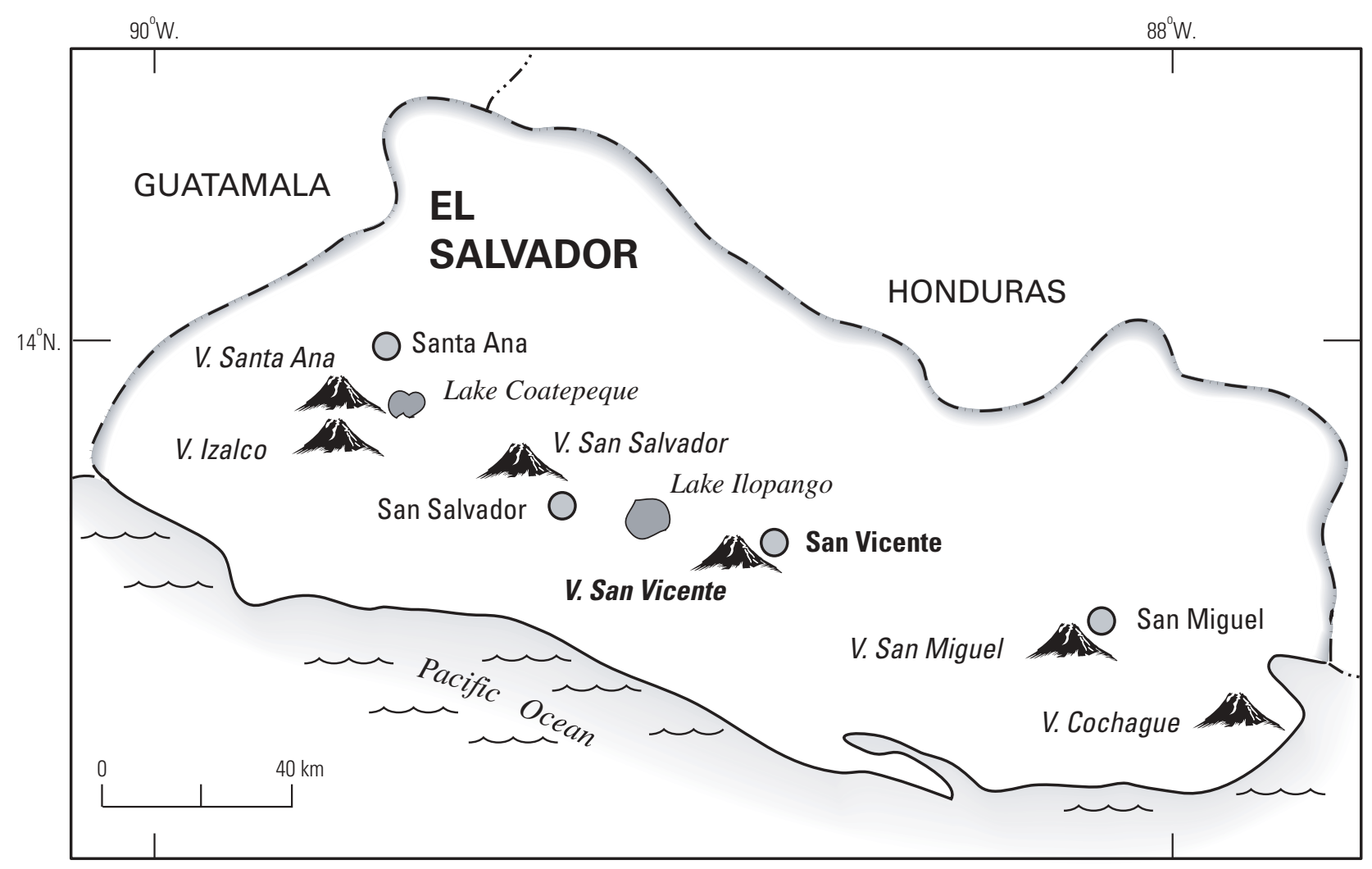

Figure 1. Location of major cities and significant Quaternary volcanoes in El Salvador. Circles indicate major cities, triangles indicate major volcanoes. Lake Coatepeque and Lake Ilopango are large silicic calderas. 


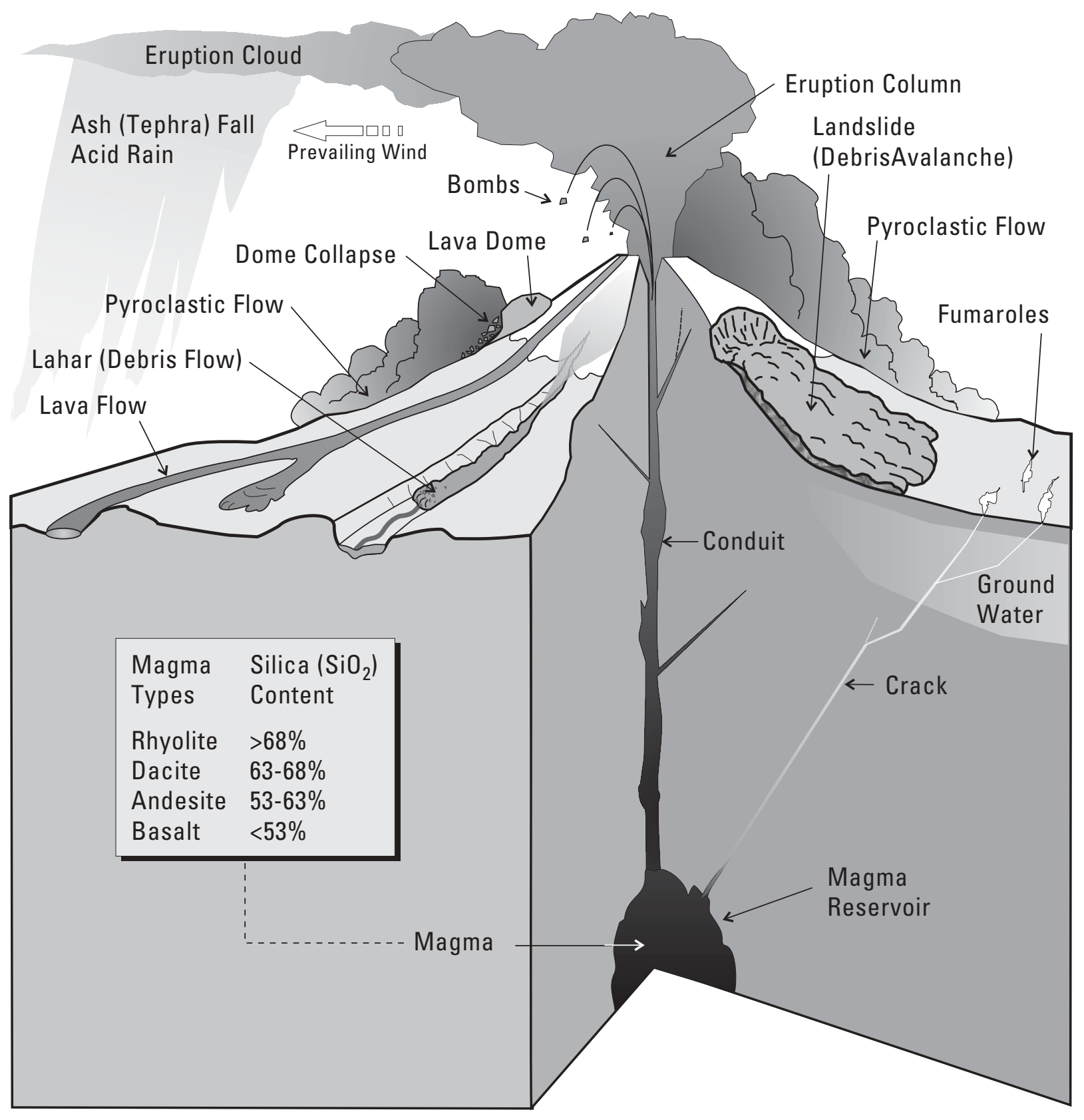

Figure 2. Simplified sketch showing hazardous events associated with a volcano like San Vicente. Events such as lahars and landslides (debris avalanches) can occur even when the volcano is not erupting. Inset box shows classification of magma types on the basis of silica content. Illustration by Bobbie Meyers, modified from USGS Fact Sheet 002-97 
They can move at such rapid speeds, 50 to 150 kilometers per hour, that escape from their paths is difficult or impossible. Temperatures in pyroclastic flows and surges commonly are several hundred degrees Celsius or more. Owing to their high density, high velocity, and high temperature, pyroclastic flows can destroy all structures and kill all living things in their paths by impact, burial, or incineration. Although pyroclastic surges are more dilute and less dense than pyroclastic flows, surges can affect larger areas and still be very destructive and lethal. People and animals caught in pyroclastic surges can be killed directly by trauma, severe burns, or suffocation.

Pyroclastic flows and surges have occurred throughout the eruptive history of San Vicente. The largest and most extensive pyroclastic flows were associated with explosive eruptions that occurred before construction of the modern edifice, perhaps many tens to hundreds of thousands of years ago. Smaller pyroclastic flows and surges have occurred in association with lava-flow and lava-dome eruptions. Some pyroclastic-flow deposits are found as far as 15 kilometers from the present summit of the volcano, but their relation to the eruptive history of the volcano is unclear.

\section{Lava flows and lava domes}

Lava is liquid magma that has reached Earth's surface nonexplosively. Depending on its viscosity and rate of discharge, lava will form a bulbous lava dome over a vent or a lava flow that can travel several kilometers or more down slope from a vent. Lava flows commonly move down slope as streams of molten rock a few to tens of meters thick. The rate at which lavas flow depends chiefly upon their chemical composition. The more silica in a lava, the more viscous it is and the more sluggishly it moves (see inset figure 2). Basaltic lavas ( $<53 \%$ silica) of the kind observed in Hawaii can move rapidly, at tens of meters per minute, whereas andesitic lavas (silica contents ranging from about $54 \%$ to $61 \%$ ) of the kind commonly erupted by the composite volcanoes in El Salvador are more sluggish and move at most at a few tens of meters per hour. Although lava flows can be extremely destructive, they typically are not life threatening. People and animals can usually walk out of the path of an advancing flow. However, fronts on sluggish lava flows moving across steep slopes can sometimes collapse and generate blocks of hot debris that cascade down slope, break apart, and form hazardous, fast-moving pyroclastic flows or surges.

Lava domes can pose a greater hazard than lava flows. Lava domes form from lava that is more viscous than that in lava flows, and as a result they can grow on steep slopes or construct steepsided landforms. As lava domes grow, they can become unstable and collapse repeatedly, also generating blocks of hot debris that cascade downslope, break apart, and form hazardous, fastmoving pyroclastic flows or surges.

Lava flows extend down all flanks of San Vicente, but have not traveled more than about 7 kilometers from the summit. Future lava flows will likely be confined to similar distances and will pose a significant hazard to developed structures and agricultural crops, but because they move so slowly they pose little threat to human life, unless a flow front collapses and generates a pyroclastic flow or surge. The location of the next lava flow at San Vicente volcano will be determined by the location and geometry of the eruption vent at that time.

Prominent lava domes are not recognized on San Vicente volcano. However, blocky pyroclasticflow deposits, similar to those associated with the collapse of lava domes at other volcanoes like San Vicente, are found interlayered with lava flows around the volcano, and they indicate that lava domes may have formed and collapsed during eruptions of the volcano. Pyroclastic flows related to lava-dome or lava-flow collapses have traveled at least 5 kilometers from the summit of the volcano; pyroclastic surges related to lava-flow or dome collapses probably traveled even farther. Pyroclastic flows formed by lava-flow or dome collapses at San Vicente volcano likely produced ash clouds that drifted many kilometers away from the volcano.

\section{Tephra}

As magma nears the surface of a volcano, gases dissolved in the magma are released. If the gas is released rapidly, then the magma can be broken explosively into small fragments and be 
dispersed into the atmosphere. Fragments from such eruptions, which range in size from microscopic ash to meter-sized blocks, are collectively called tephra. Tephras form deposits that blanket broad areas downwind from a volcano. A deposit's thickness and particle size generally decrease away from the vent, but a deposit can cover large areas tens to hundreds of kilometers from the source. The largest tephra fragments, called ballistic projectiles, fall to the ground within a few kilometers of the vent.

Tephra falls seldom threaten life directly, except within a few kilometers of a vent. Large ballistic fragments are capable of causing death or injury by impact. Large projectiles may also still be hot when they land and can start fires if they fall onto combustible material. Most injuries and fatalities from tephra falls occur when the tephra accumulations are thick, or are saturated by rainfall, and thus are heavy enough to collapse building roofs. Fine tephra suspended in the air can irritate eyes and respiratory systems and exacerbate pulmonary problems, especially in the elderly and infants.

Indirect effects of tephra falls can be perhaps more disruptive than the direct effects of tephra falls. Even thin accumulations of tephra fall can significantly disrupt social and economic activities over broad regions. Tephra plumes can create tens of minutes or more of darkness, even on sunny days, and tephra falls can reduce visibility and navigability on highways. Tephra ingested by vehicle engines can clog filters and increase wear. Deposits of tephra can short-circuit or break electric transformers and power lines, especially if the tephra is wet, sticky, and heavy. Tephra can contaminate surface-water drinking supplies, plug storm- and sanitary-sewer systems, and clog irrigation canals. Even thin tephra accumulations may ruin sensitive crops. A serious potential danger of tephra stems from the threat of even small, dilute tephra clouds to jet aircraft that fly into them. Ingestion of even small amounts of tephra into jet engines can cause them to malfunction and lose power.

Lessons learned from the 1980 eruption of Mount St. Helens in the United States can help governments, businesses, and citizens to prepare for future tephra falls. Communities downwind of
Mount St. Helens experienced significant disruptions in transportation, business activity, and services from fallout of as little as 5 millimeters of tephra. The greater the amount of tephra fall, the longer it took for a community to recover. As perceived by residents, tephra falls of less than 5 millimeters were a major inconvenience, whereas falls of more than $150 \mathrm{~mm}$ constituted a disaster. Nonetheless, all of the downwind communities affected by Mount St. Helens resumed normal activity within about two weeks of the event.

The San Vicente volcano complex produced voluminous, extensive tephra fall deposits once in its eruptive history. Those tephra fall deposits are associated with a series of major explosive eruptions that occurred less than 1 million years ago, but before construction of the modern edifice. Since then San Vicente volcano has not erupted extensive tephras. Instead, modest amounts of tephra have been produced during lava-flow and lava-dome eruptions. Most tephra fallout around the volcano has come from clouds of sand- and silt-sized particles that rose from moving pyroclastic flows produced perhaps by lava-dome collapse. Such clouds of tephra probably rose several thousands of meters into the air and drifted downwind. Depending upon wind directions at the time of an eruption, future lava-flow and lava-dome eruptions at San Vicente could produce tephra clouds that affect communities such as San Vicente, Tepetitan, Tecoluca, and Zacatecoluca, among others. However, tephra fallout from these types of eruptions poses little threat to life or structures in nearby communities.

\section{Volcanic gases}

All magmas contain gases that are released both during and between eruptions. Volcanic gases consist mainly of steam but also include carbon dioxide and compounds of sulfur and chlorine, and minor amounts of several other gases.

Generally, volcanic gases are diluted rapidly downwind from the vent, but within a few kilometers of a vent they can endanger life and health if concentrations are high and exposure is prolonged. Eyes and lungs of people and animals can be injured by acids, ammonia, and other compounds. 
People and animals can suffocate in denser-than-air gases like carbon dioxide, which pond and accumulate in closed depressions.

The greatest hazards arising directly from gases emitted at San Vicente volcano are likely to be confined to the summit crater, and thus of concern to those who work or recreate within the crater. Outside the summit crater, direct hazards from volcanic gases are likely to be minor.

A wider spread, but indirect, hazard arising from volcanic gases emitted by San Vicente volcano involves formation of acid rain. Compounds of sulfur are one of the main gases emitted by volcanoes, and excessive acidification of rainfall can occur when sulfur compounds combine with water vapor and droplets and form sulfuric acid that is deposited during storms. If such acid is sufficiently concentrated it can damage crops, reduce land productivity, and pollute surface water. In El Salvador, acid rain resulting from emission of volcanic gases has damaged coffee crops locally, particularly around Santa Ana volcano [2].

\section{Debris avalanche, landslide, and lahar}

The slopes of a volcano may become unstable and fail catastrophically, generating a rapidly moving landslide called a debris avalanche. Slope instability at volcanoes can be caused by many factors. Magma rising upward through a volcano can push aside older volcanic rock and deform and steepen the flanks of a volcano, or warm acidic ground water can circulate through cracks and porous zones inside a volcano, alter strong rock to weak slippery clay, and gradually weaken the volcano so that it is susceptible to debris avalanches. A volcano's slopes can also fail without direct involvement of magma. Unexpected earthquakes, torrential rains, or steam explosions can trigger slope failures, but these failures are commonly smaller in volume than those triggered by magmatic intrusion. A debris avalanche can attain speeds in excess of 150 kilometers per hour; generally, the larger the avalanche, the faster and farther it can travel. Small-volume debris avalanches typically travel only a few kilometers from their source, but large-volume debris avalanches can travel tens of kilometers from a volcano. Debris avalanches destroy everything in their paths and can leave deposits of 10 meters to more than 100 meters thick on valley floors.

Deposits of at least one large debris avalanche have been recognized southeast of San Vicente, in the vicinity of Tecoluca, suggesting that a large segment of the volcano collapsed at least once in a massive prehistoric landslide. The full extent of this avalanche and its associated lahar is not precisely known, but it appears to have reached the Río Lempa, 25 kilometers from the volcano.

Lahars, also called mudflows and debris flows, are flowing masses of mud, rock, and water that look much like flowing concrete. They are produced when water mobilizes large volumes of loose mud, rock, and volcanic debris. Commonly, landslides and debris avalanches will transform into lahars as they move down valley. Lahars, like floods, inundate floodplains and submerge structures in low-lying areas. They can travel many tens of kilometers at speeds of tens of kilometers per hour. Lahars can destroy or damage everything in their paths through burial or impact. They follow river valleys and leave deposits of muddy sand and gravel that can range from a few to tens of meters thick. They are particularly hazardous because they travel farther from a volcano than any other hazardous phenomenon except tephra, and they affect stream valleys where human settlement is usually greatest. In some instances, landslides and lahars can clog a channel or block a tributary channel and impound a lake behind the blockage. Commonly, the impounded water will spill over the blockage, quickly cut a channel, catastrophically drain the lake, and generate a flood that moves down the valley endangering people and property. Breaching of the blockage may occur within hours to months after impoundment.

Like floods, lahars range greatly in size. The smallest lahars recur most frequently (perhaps every few years), whereas the largest recur on the order of centuries to millennia. The size of lahars is controlled by both the amount of water and the amount of loose sediment or volcanic debris available. Large debris avalanches or eruptions can dump tens to hundreds of millions of cubic meters of sediment into channels and produce large lahars. Small debris avalanches or eruptions produce smaller lahars. Deposits of ancient lahars are 
found in several channels around San Vicente volcano, and historical landslides and lahars of more than 100,000 cubic meters in volume have failed from all sides of the volcano's steep upper slopes and have traveled more than 6 kilometers from their sources [1].

Landslides and lahars can cause problems long after the event that formed them ends. Once landslides and lahars fill stream channels with sediment, the streams begin to erode new paths, and the new stream channels can be highly unstable and shift rapidly as sediment is eroded and moved farther down valley. Rapid stream shifting can cause rapid and dramatic bank erosion. Also, because stream channels are clogged with sediment, they have less ability to convey water. As a result, relatively small floods, which may have previously passed unnoticed, can pose potentially significant threats to people living in low-lying areas. In general, people living in low-lying areas along river valleys are most susceptible to these secondary affects from landslides and lahars, but areas on higher ground adjacent to river channels apparently safe from flooding may be threatened by bank erosion. Examples from many volcanoes around the world show that the effects of sediment deposition by landslides and lahars in stream channels can persist for years to decades [3].

\section{PAST EVENTS AT SAN VICENTE VOLCANO}

Details of the eruptive history of San Vicente volcano are poorly known. The last major eruption occurred more than 1700 years ago, and probably occurred long before permanent human habitation of the area ( 2000 B.C.). Nevertheless, we do know that a volcanic complex at San Vicente has a history that extends more than 2 million years, and that it has exhibited highly explosive eruptions as well as emplacement of lava flows and lava domes.

Previous studies recognize the existence of at least a three-stage evolution of San Vicente volcano [1]. The oldest rocks at San Vicente are between 1 million and 2 million years old and are associated with a series of pronounced hills that lie immediately west-northwest of the volcano. These hills delineate the edge of an annular feature thought to be the remnants of an older volcanic center, known as La Carbonera. Lava flows extruded over hundreds of thousands of years built the $\mathrm{La}$ Carbonera complex.

Sometime after about 1 million years ago, relatively quiescent emplacement of basaltic and andesitic lavas at the ancestral La Carbonera volcanic center was interrupted by a phase of major explosive activity. The explosive eruptive phase produced pyroclastic flows, pyroclastic surges and thick tephra fall. Deposits of this explosive phase of activity are rich in dacite pumice, a light frothy fragment of exploded magma having a silica content ranging from $63 \%$ to $68 \%$, which indicates that gas-rich magma intruded the volcano and erupted violently. The earliest deposits from this phase of activity are separated from later deposits by a thick, well developed paleosol, a buried soil horizon, indicating that the explosive phase extended over many thousands of years. The compositions, textures, and distributions of some nonpumiceous tephra and surge deposits within the sequence of deposits related to this explosive phase of activity indicate that some explosions were phreatomagmatic and involved interactions of magma and water. The timing of this explosive phase of activity is unknown. Development of a pair of thick, well developed paleosols within this sequence of deposits as well as the construction of the modern San Vicente volcano after this explosive eruptive phase ended suggest that this period of explosive activity occurred many tens to hundreds of thousands of years ago.

The modern San Vicente volcano was built after the phase of explosive activity. Its edifice consists of two prominent cones that are composed largely of andesite lava flows. On the basis of their morphology, the easternmost cone appears to be the youngest, suggesting that the focus of volcanism at this center has migrated east-northeastward with time. Local deposits of nonpumiceous pyroclastic flows interlayered with the lava flows suggest that construction of the modern edifice included growth and collapse of small-volume lava domes.

Mass movements of sediment from the volcano by landslides, lahars, and pyroclastic flows, and reworking of that sediment by streamflow, have formed an apron of debris that has accumulated at 
the base of the volcano. Of particular significance is an extensive lahar-like deposit southeast of the volcano that contains many small hills, composed of volcanic rock and debris, known as hummocks. This deposit, found near and southeast of Tecoluca, extends at least as far as the Río Lempa, 25 kilometers from the volcano, and represents a debris avalanche and associated lahar that resulted from collapse of a massive segment of the volcano.

Most of the deposits in the apron of debris accumulated at the base of the volcano are probably many thousands of years old. They commonly are weathered and capped by a well developed soil horizon, and are overlain by the Tierra Blanca Joven (TBJ) deposit, the youngest tephra deposit from an eruption of Ilopango caldera. The TBJ deposit is more than 1700 years old [4].

Although there has been no historical eruptive activity at San Vicente volcano, lethal, and potentially lethal, volcano-related events have occurred several times. Known earthquake- and rainfalltriggered landslides and lahars occurred in 1774, 1934, 1996, and 2001 [1]. Others may have occurred in historical time, but are not recorded. The 1774 lahar occurred on the northeast flank of the volcano and affected the village of San Vicente. The 1934 lahar occurred on the north flank of the volcano and destroyed the village of Tepetitan, more than 6 kilometers from the summit of the volcano. Landslides and lahars on the south flank of the volcano in 1996 damaged the major roadway between Tecoluca and Zacatecoluca. Landslides triggered by an earthquake in February 2001 occurred on the north and northwest flanks of the volcano, but they did not transform into lahars that flowed down valley. However, these landslides dumped more than 200,000 cubic meters of sediment into channels that drain the volcano, and potential remobilization of that sediment poses an increased risk from destructive floods and lahars to the downstream communities of Guadalupe and Tepetitan. In September 2001, a rainfall-triggered lahar from the northwest flank of the volcano, which possibly formed in material loosened by the February 2001 earthquake, damaged the town of Guadalupe.

\section{FUTURE ACTIVITY AT SAN VICENTE VOLCANO}

Although San Vicente volcano has a lack of historical eruptive activity and a poorly known eruptive history, vigorous hot springs and geothermal development located on the north side of the volcano suggest that past eruptions are youthful enough that the volcanic system maintains residual heat from magmatic sources. As a result, the volcano should be considered active and likely to erupt again.

On the basis of past eruptive activity, future eruptive activity at San Vicente volcano will most likely involve emplacement of lava flows and growth and collapse of small-volume lava domes. Collapse of lava domes will generate small pyroclastic flows and surges that may travel several kilometers beyond the base of the volcano. Tephra fall associated with such eruptive events may travel 10 kilometers or more from the volcano. The volcano has, however, erupted violently in the past and could do so again in the future. Explosive eruptions are more dangerous than those that emplace lava flows or lava domes. Explosive eruptions can produce large pyroclastic flows and surges that simultaneously affect multiple sectors of the volcano, as well as produce tephra falls and lahars that could affect areas more than 10 kilometers from the volcano. Landslides and lahars, triggered by any of several mechanisms, can occur on any flank of the volcano.

Although the volcano has erupted violently in its past, it apparently has not done so since the present cone was constructed. Because thousands of years have elapsed since its last significant eruption, it is difficult to forecast the style of future eruptions. If precursory volcanic activity, such as increased seismicity within the cone, increased gas emission, and edifice deformation, is detected at San Vicente volcano it would be prudent to anticipate explosive activity at the onset of an eruption.

The largest magnitude events that are possible at San Vicente volcano have very low annual probabilities, but if they occur they will have very serious consequences. Although preparing for such rare events is not warranted, understanding potential extreme-case scenarios is nonetheless prudent. 
As demonstrated by the catastrophic 1980 eruption of Mount St. Helens in the United States, two types of large-scale hazardous events can occur at volcanoes like San Vicente-- a large-volume debris avalanche and lahar, and a large directed blast (a type of highly mobile pyroclastic flow). Hazard zones for such catastrophic events are shown on the accompanying hazard-zonation map (plate 1).

The primary effects of future eruptions or landslides at San Vicente will likely be confined to within about 10 kilometers of the summit of the volcano. However, large lahars could travel more than 10 kilometers from the summit, and tephra fall could be carried more than 10 kilometers downwind.

Upper-level wind patterns in Guatemala between 3000 and 15,000 meters altitude are strongly seasonal [5]. Similar wind patterns are likely in El Salvador. From January to March, westerly winds dominate. April and May are transitional months in which westerly winds give way to more northerly and easterly winds. June through October are characterized by easterly winds, and November and December are transitional months during which westerly winds gradually become dominant. The strong seasonality of these winds will influence areas affected by tephra falls. Erupted tephras will likely fall eastward of the volcano from January through March, potentially cover broad regions to the east, south, and west in April and May, affect areas west of the volcano from June through October, and possibly areas west, north, and east of the volcano in November and December. Surface winds may also affect tephra distributions, and their patterns are diurnal as well as seasonal [5]. Therefore, all sectors around San Vicente volcano can be affected by tephra fall, but some areas are more likely to be affected than others depending upon the season in which an eruption occurs.

The primary effects of eruptions and landslides are serious, but secondary effects can be equally as severe, can affect areas that are beyond the zone of primary impact, and can linger for several years. Such secondary effects, which are chiefly associated with sediment deposited in river channels by landslides and lahars, involve reworking and redistribution of sediment, bank erosion, loss of channel capacity, and enhanced hazards of floods in low- lying areas. Secondary effects that occur in the aftermath of an eruption of San Vicente volcano or a large landslide off the volcano can affect areas many tens of kilometers downstream from the volcano.

\section{EVENTS AT OTHER VOLCANOES CAN AFFECT THE SAN VICENTE REGION}

San Vicente volcano is not the only source of volcanic hazards in the region. The most devastating volcanic events that have affected the San Vicente region are related to large explosive eruptions from Ilopango caldera, which is located to the west of San Vicente (figure 1). Four explosive eruptions from this caldera within approximately the past 40,000 to 50,000 years [4] left tephra-fall and pyroclastic-flow deposits that are as much as several meters thick in the San Vicente region. Deposits of the youngest explosive eruption from Ilopango, the regional Tierra Blanca Joven (TBJ) unit, are dated at 260 A.D. [4], and these deposits extend from several kilometers east of San Vicente volcano to several kilometers west of San Salvador volcano (figure 1). Such large catastrophic eruptions of Ilopango occurred about once every 10,000 to 15,000 years during the past 40,000 to 50,000 years, so the annual probability of another eruption of this magnitude at Ilopango is very low. Depending upon the season and prevailing wind directions, tephra from eruptions of other volcanoes such as Santa Ana, San Salvador, and San Miguel (figure 1), for example, could affect the San Vicente region.

Cerro Ramirez is a small volcano that formed on the lowermost northeast flank of San Vicente volcano near the town of San Vicente. Very little is known about this volcano, but future eruptive activity at this site will pose significant risk to local populations, particularly to the town of San Vicente.

North-northeast of San Vicente volcano lies the Apastepeque volcanic field, a dense cluster of about 25 small volcanoes contained within an area of about 65 square kilometers [1]. These volcanoes consist of small domes, cinder cones, and explosion craters. Eruptions of these volcanoes are similar to those of the small monogenetic volcanoes that surround San Salvador volcano, and include explo- 
sive ejection of tephra, lava flows, and possibly pyroclastic flows and pyroclastic surges. Future eruptions of the Apastepeque volcanic field may produce tephra falls that accumulate thinly on communities mainly to the north of San Vicente volcano.

\section{VOLCANO-HAZARD-ZONATION MAP}

Because the details of past eruptions at San Vicente are poorly known, we rely on information about the effects and consequences of eruptions from volcanoes around the world that are similar to San Vicente volcano to gain a general idea of possible eruption scenarios and hazards. This is a reasonable method because similar types of events occur at many volcanoes, even though the exact types of events that occur, and their relative frequencies and sizes, vary among volcanic centers.

The accompanying volcano-hazard-zonation map (plate 1) shows areas that could be affected by future hazardous geologic events at San Vicente volcano. Individual events typically affect only part of a hazard zone. The location and size of an affected area will depend on the location of an erupting vent or landslide, the volume of material involved, and the character of an eruption, especially its explosivity.

Potentially hazardous areas around San Vicente volcano are divided into proximal-volcanic and lahar hazard zones depending primarily on the type of hazard. The lahar hazard zones are subdivided further on the basis of the relative degree of hazard from lahars of various volumes. Hazard-zone boundaries are drawn on the basis of (1) the magnitude of past events at the volcano, as inferred from deposits; (2) mathematical models that use calibrations from other volcanoes to predict the probable extent of lahars; and (3) our experience and judgement derived from observations and understanding of events at similar volcanoes.

Although we show sharp boundaries for hazard zones, the limit of the hazard does not end abruptly at these boundaries. Rather, the hazard decreases gradually as distance from the volcano increases, and for lahars decreases rapidly with increasing elevation above channel floors. Areas immediately beyond outer hazard zones should not be regarded as hazard-free, because the limits of the hazard can be located only approximately, especially in areas of low relief. Many uncertainties about the source, size, and mobility of future events preclude locating the boundaries of zero-hazard zones precisely.

Users of the hazard map in this report should be aware that the map does not show all hazardous areas subject to landslides and lahars from San Vicente volcano. The volcano is extensively incised, and landslides could occur in any drainage. For this report we defined zones of inundation from lahars of various volumes for prominent channels directed toward populous areas. Other channels for which we have not modeled lahar inundation should not be considered as areas devoid of lahar hazard. Landslides and lahars from other unmapped channels could just as well threaten life and property.

\section{Proximal volcanic hazard zone}

The proximal volcanic hazard zone includes areas immediately surrounding San Vicente volcano, and extends about 8 to 10 kilometers outward from the summit depending upon local topography [6]. This zone delineates areas subject to devastating volcanic phenomena including pyroclastic flows and surges, debris avalanches, lava flows, and ballistics. Owing to the speed and destructiveness of many of these phenomena, escape or survival is unlikely in the proximal volcanic hazard zone. Therefore, evacuating this hazard zone during periods of volcano unrest is realistically the only way to protect lives. Debris avalanches and lahars will originate in the proximal area, and deposits from slides and flows less than about 500,000 cubic meters in volume will likely be restricted to this zone. Larger debris avalanches and lahars will travel away from the volcano and onto adjacent lowlands. The extent of inundation from lahars of various volumes is the basis for defining the lahar hazard zones.

\section{Lahar hazard zones}

Lahar hazard zones lie primarily along channels that drain San Vicente volcano. Depending on the distance from the volcano, these areas will be affected a few minutes to about one hour after the 
onset of a lahar. Beyond 10 kilometers from the volcano's summit escape may be possible if people are given sufficient warning. Within 10 kilometers of the volcano lahars may happen too quickly to provide effective warning.

We used a mathematical technique calibrated with data from other volcanoes [7] to estimate potential areas of inundation by lahars of various volumes. For each channel analyzed, we define four nested hazard zones that depict anticipated inundation by hypothetical "design" lahars having different volumes. The largest design lahar selected for initiation within a single channel, 1 million cubic meters, reflects our estimate of the largest probable lahar that could be triggered by earthquakes or torrential rains at San Vicente [7]. We also define a hazard zone that depicts anticipated inundation by a lahar having a volume of 100 million cubic meters. A lahar of this size reflects our estimate of the largest probable debris avalanche that might descend suddenly from San Vicente volcano [7]. A debris avalanche of this size requires catastrophic failure of a very large part of the volcano, followed by complete transformation of the avalanche into a lahar. Such an event might occur in conjunction with volcanic activity, such as intrusion of magma into the edifice, that would be detected by monitoring. However, the possibility that large flank failures could be triggered by mechanisms other than magma intrusion, such as by weakening of rock by hydrothermal alteration, strong earthquakes, or torrential rains cannot be dismissed. In general, landslides and lahars triggered by mechanisms other than volcanic activity are most likely to be smaller than 1 million cubic meters in volume.

The intermediate $(300,000$ to 500,000 cubic meters) and smallest (100,000 cubic meters) design lahars are more typical lahar volumes for a small to moderate eruption or for a landslide that occurs without warning. Lahars of these sizes have occurred historically at San Vicente volcano, and lahars of these sizes and smaller are the most likely sizes to occur again.

Large lahars are less likely to occur than small lahars. Thus, the nested lahar-hazard inundation zones show that the likelihood of lahar inundation decreases as distance from the volcano and eleva- tion above the valley floors increases. The annual probability of lahars of various sizes is difficult to estimate. Ages and extents of lahars having volumes of 1 million cubic meters or more from San Vicente are unknown, but lahars of this size probably have an annual probability of less than 1 in 50,000 to 1 in 10,000 on the basis of soil development on such deposits [8]. Smaller landslides and lahars triggered by earthquakes or torrential rains are much more likely to occur, but would probably inundate only parts of the design hazard zones adjacent to stream channels. Lahars of about 500,000 cubic meters or less may have an annual probability of about 1 in 50 to perhaps as great as 1 in 10 [8].

In general, lahar hazard zones are within about 10 kilometers of the summit crater, and fall mostly within the proximal volcanic hazard zone. The hazard zone for the largest volume design lahar of 100 million cubic meters, representing catastrophic, massive flank failure, extends as much as 25 kilometers from the summit crater and broadly covers the landscape surrounding the volcano. Local topography plays a large role in controlling the runout of smaller lahars. Although landslides and lahars originate in and flow along steeply incised drainages on the flanks of the volcano, these channels abruptly shallow and the topography abruptly flattens near the base of the edifice. As a result, lahars rapidly spill out of channels, spread, and stop. The most distant hazard zones are associated with the deepest incised channels in which lahars remain confined, particularly along the northern half of the San Vicente region. Despite their relatively short runout distances, even the smallest lahars can be devastating. All major communities near the volcano are located within 10 kilometers of the summit. Our results suggest that the communities located generally northwest to northeast of San Vicente volcano are at greatest risk from inundation by lahars. However, several smaller communities and coffee plantations are located on the lower flanks of the volcano, and the hazard zones of even the smallest lahars extend well into areas that are now settled or used for agriculture. 


\section{HAZARD FORECASTS AND WARNINGS}

Scientists normally can recognize and monitor several indicators of impending volcanic eruptions. Magma rising into a volcano prior to an eruption causes changes that can usually be detected by various geophysical instruments and visual observations. Swarms of small earthquakes are generated as rock breaks to make room for rising magma or as heating of fluids increases underground pressures. Heat from the magma can increase the temperature of ground water and raise temperatures of hot springs and steaming from fumaroles; it can also generate small steam explosions. The composition and volume of gases emitted by fumaroles can change as magma nears the surface, and injection of magma into a volcano can cause swelling or other types of surface deformation.

El Salvador has a national seismic network, so a significant swarm of earthquakes at San Vicente volcano would be noticed quickly. At other volcanoes similar to San Vicente, notable increases in seismicity have occurred days to months before eruptions. An increase in seismicity near the volcano should prompt deployment of additional seismometers to better locate earthquakes, and stimulate other monitoring efforts that examine signs of volcanic unrest.

Periods of unrest at volcanoes produce times of great uncertainty. During the past few decades substantial advances have been made in volcano monitoring and eruption forecasting, but still scientists can often make only very general statements about the probability, type, and scale of an impending eruption. Precursory activity can go through accelerating and decelerating phases, and sometimes will die out without an eruption. Government officials and the public must realize the limitations in forecasting eruptions and must be prepared to cope with such uncertainty.

Despite advances in volcano monitoring and eruption forecasting, it is still difficult, if not impossible, to predict the precise occurrence of landslides triggered by earthquakes or torrential rains. Therefore, government officials and the public need to identify the locations of lahar hazard zones and realize that potentially lethal events in these hazard zones can occur with little or no warning.

\section{Protecting Communities and Citizens from Volcano-Related Hazards}

Communities, businesses, and citizens must plan ahead to mitigate the effects of future volcanic eruptions, landslides, and lahars from San Vicente volcano. Long-term mitigation efforts must include using information about volcano hazards when making decisions about land use and siting of critical facilities. Future development should avoid areas judged to have an unacceptably high risk or be planned and designed to reduce the level of risk.

When volcanoes erupt or threaten to erupt, a rapid, well-coordinated emergency response is needed. Such a response will be most effective if citizens and public officials have a basic understanding of volcano hazards and have planned the actions needed to protect communities.

Because an eruption can occur within days to months after the first precursory activity and because some hazardous events, such as landslides and lahars, can occur without warning, suitable emergency plans should be made in advance. Although it has been more than 2000 years since San Vicente volcano last erupted significantly and it is unknown when it may erupt again, public officials need to consider issues such as public education, land-use planning, communication and warning strategies, and evacuations as part of a response plan. Emergency plans already developed for floods may apply to some extent, but may need modifications for hazards from lahars. For habitats in low-lying areas, a map showing the shortest route to high ground will also be helpful for evacuations.

Knowledge and advance planning are the most important items for dealing with volcano hazards. Especially important is a plan of action based on the knowledge of relatively safe areas around homes, schools, and workplaces. All of the volcano hazards described in this report are serious, and many different hazardous phenomena may affect an area that extends as much as 10 kilometers from the summit of San Vicente volcano. Lahars pose the biggest threat to people living, working, or 
recreating along channels that drain San Vicente volcano. The best strategy for avoiding a lahar is to move to the highest possible ground. A safe height above river channels depends on many factors including the size of the lahar, distance from the volcano, and shape of the valley. For areas beyond about 8 kilometers from the summit of the volcano, all but that largest lahars will rise less than 20 meters above river level. San Vicente volcano will erupt again, and the best way to cope with future eruptions is through advance planning in order to mitigate their effects.

\section{REFERENCES}

Baum, R.L., Crone, A.J., Escobar, D., Harp, E.L., Major, J.J., Martinez, M., Pullinger, C.R., and Smith, M.E., 2001, Assessment of landslide hazards resulting from the February 13, 2001, El Salvador earthquake: U.S. Geological Survey Open-File Report 01-119, 22 p.

Brauer, J., Smith, J., and Wiles, V., 1995, On your own in El Salvador: On Your Own Publications, Portland, OR, $260 \mathrm{p}$.

Hart, W.J.E., and Steen-McIntyre, V., 1983, Tierra Blanca Joven tephra from the A.D. 260 eruption of Ilopango caldera, in Sheets, P.D., ed., Archaeology and Volcanism in Central America: University of Texas Press, Austin, p. 14-34.

Hayashi, J.N., and Self, S., 1992, A comparison of pyroclastic flow and debris avalanche mobility: Journal of Geophysical Research, v. 97, p. 9063-9071.

Iverson, R.M., Schilling, S.P., and Vallance, J.W., 1998, Objective delineation of lahar-hazard zones downstream from volcanoes: Geological Society of America Bulletin, v. 110, p. 972-984.

Major, J.J., Pierson, T.C., Dinehart, R.L., and Costa, J.E., 2000, Sediment yield following severe volcanic disturbance--a two decade perspective from Mount St. Helens: Geology, v. 28, p. 819-822.

Malin, M.C., and Sheridan, M.F., 1982, Computerassisted mapping of pyroclastic surges: Science, v. 217 , p. $637-640$.

Mercado, R., Rose, W.I., Najera, L., Matías, O., and Girón, J., 1988, Volcanic ashfall hazards and upper wind patterns in Guatemala, preliminary report: Publication of Department of Geological Engineering and Sciences, Michigan Technological University: Houghton, MI, 34 p.

Portig, W.H., 1976, The climate of Central America, in Schwerdtfeger, W., ed., World Survey of Climatology, Climates of Central and South America, v. 12: Elsevier, New York, p. 405-478.

Romano, L., 1997, Catalogo de desastres, accidentes y ecologia (1915-1990): Centro de Proteccion de Desastres.

Rose, W.I., Conway, F.M., Pullinger, C.R., Deino, A., and McIntosh, W.C., 1999, An improved age framework for late Quaternary silicic eruptions in northern Central America: Bulletin of Volcanology, v. 61, p. 106-120.

Rotolo, S.G., Aiuppa, A., Pullinger, C.R., Parello, F., Tenorio-Mejica, J., 1998, An introduction to San Vicente (Chichontepec) volcano, El Salvador: Revista Geológica de América Central, v. 21, p. 25-36.

Rotolo, S.G., and Castorina, F., 1998, Transition from mildly-tholeiitic to calc-alkaline suite: the case of Chichontepec volcanic center, El Salvador, Central America: Journal of Volcanology and Geothermal Research, v. 86, p. 117-136.

Rymer, M.J., and White, R.A., 1989, Hazards in El Salvador from earthquake-induced landslides, in Brabb, E.E., and Harrod, B.L., eds., Landslides: Extent and Economic Significance. Balkema, Rotterdam, p. 105-109.

Williams, H., and Meyer-Abich, H., 1955, Volcanism in the southern part of El Salvador: University of California Publications in Geological Sciences, v. 32,64 p.

\section{ADDITIONAL SUGGESTED READING}

Blong, R.J., 1984, Volcanic hazards: Academic Press, Orlando, $424 \mathrm{p}$.

Sigurdsson, H., Houghton, B., McNutt, S.R., Rymer, H., and Stix, J., eds., 2000, Encyclopedia of Volcanoes: Academic Press, San Diego, CA., $1417 \mathrm{p}$.

Tilling, R.I., ed., 1989, Volcanic hazards: Short course in geology, v. 1, American Geophysical Union, Washington, D.C., 123 p. 


\section{END NOTES}

[1] The geologic data upon which this report is based come largely from Rotolo et al. (1998);

Rotolo and Castorina (1998); Williams and Meyer-Abich (1955); communications with personnel at Centro de Investigaciones Geotécnicas, San Salvador; and our own reconnaissance investigations. There is no record of historical eruptive activity of San Vicente volcano, although Williams and MeyerAbich (1955) make a vague reference to an unconfirmed eruption in 1643. Information on historical landslides and lahars comes mainly from interviews of elderly residents of Tepetitan, communications with personnel at Centro de Investigaciones Geotécnicas and Geothermal Salvadorena, Brauer et al. (1995), Romano (1997), and Baum et al. (2001).

[2] Diario del Hoy reported on gas emissions, acid rain, and crop damage at coffee plantations around Santa Ana volcano in a story published on January 19, 2001.

[3] Analyses of limited data from volcanoes around the world indicate that sediment yields from river channels filled with volcanic debris by an eruption can remain higher than typical background levels for years to decades after an eruption. In some cases sediment yields can remain 10 to 100 times greater than typical background levels for more than two decades (Major et al., 2000). River channels heavily clogged with sediment typically are unstable. Heavy sediment deposition causes a river to wander across the valley floor, which can trigger significant bank erosion that further adds to a river's sediment load.

[4] Ages of eruptions from large silicic calderas in Central America are given in Rose et al. (1999). Detailed discussion of the Tierra Blanca Joven (TBJ) tephra from Ilopango caldera is given in Hart and Steen-McIntyre (1983).

[5] Upper-level wind patterns in Guatemala are given in Mercado et al. (1988). Diurnal and seasonal surface-wind patterns in San Salvador are given in Portig (1976).

[6] The maximum extent of the proximal volcanic hazard zone is estimated from the formula $\mathrm{H} / \mathrm{L}=0.2$, where $\mathrm{H}$ is the elevation difference between the summit of San Vicente volcano and the hazard boundary line, and $\mathrm{L}$ is the horizontal distance from the center of the summit to the hazard boundary line (see, for example, Malin and Sheridan, 1982; Hayashi and Self, 1992; and Iverson et al., 1998). The value 0.2 was selected because it is consistent with the $\mathrm{H} / \mathrm{L}$ ratio of proximal hazardous phenomena at many other volcanoes.

[7] Lahar hazard zones were constructed by modeling lahar volumes of 100,000; 300,000; 500,000; 1 million; and 100 million cubic meters. Using mathematical and digital cartographic techniques (Iverson et al., 1998), these volumes were used to compute the estimated extent of inundation down stream from a source area. Although there have been at least four large landslides and lahars at San Vicente volcano within the past 225 years, the volumes of these events are rather ill-constrained. Landslides at San Vicente volcano triggered by a large $\left(M_{w}\right.$ 6.6) earthquake in February 2001 had estimated volumes as great as 250,000 cubic meters (Baum et al., 2001). Regional earthquake- and rainfall-triggered landslides have had volumes of more than 10 million cubic meters, but most landslides triggered by these mechanisms have had volumes of a few hundred to a few tens of thousands of cubic meters (Rymer and White, 1989; Baum et al., 2001; E.L. Harp and A.J. Crone, U.S. Geological Survey, personal communication). At Casita volcano in Nicaragua, extremely heavy rainfall from Hurricane Mitch triggered a landslide of about 1.5 million cubic meters in volume, but as it moved down slope it transformed into a lahar that scoured its channel and its volume enlarged to more than 3 million cubic meters (K.M. Scott, U.S Geological Survey, personal communication). On the basis of these data, we select a landslide and associated lahar of 1 million cubic meters to be a probable maximum size likely to be triggered in any single channel at San Vicente volcano by earthquakes or torrential rainfalls.

A volume of 100 million cubic meters is considered to be the largest likely debris avalanche from San Vicente volcano, on the basis of the following analogy to the 1980 debris avalanche of Mount St. Helens. The 1980 Mount 
St. Helens avalanche removed about 2300 million cubic meters from the north flank of the volcano, which had an average slope of about 30 degrees. This avalanche removed about $25 \%$ of the cone's total volume above the altitude at which the failure plane intersected the lower north flank. Similar to Mount St. Helens, San Vicente volcano is a massive, steep sided edifice, but one that is extensively incised. Slopes above 1600 meters altitude equal or exceed 30 degrees, and the volume of San Vicente volcano above this altitude is about 1 billion cubic meters. However, that is the volume of the combined "dual" edifice. Each separate cone of San Vicente volcano has a volume of about 500 million cubic meters. If we assume that magma would most likely intrude one cone rather than both simultaneously, and apply the $25 \%$ value from Mount St. Helens to San Vicente, then the maximum probable volume of a large debris avalanche and associated lahar is slightly more than 100 million cubic meters. For modeling purposes we have rounded this volume downward to 100 million cubic meters. San Vicente has collapsed in a massive landslide at least once in its history; however, the volume of that collapse and associated lahar is unknown.

[8] The annual probability of a lahar having a volume that equals or exceeds 1 million cubic meters is probably less than 1 in 10,000. Lahar deposits around San Vicente volcano having such approximate volumes are capped by well developed soil horizons that are grossly similar to or older than those that cap some of the Quaternary tephra deposits from eruptions of Ilopango caldera (the TB2, TB3, and TB4 units), and the deposits from those caldera eruptions have been estimated to range from about 15,000 to 50,000 years old (Rose et al.,
1999; J.W. Vallance, U.S. Geological Survey, personal communication). We estimate possible annual probabilities of landslides and lahars having volumes of 500,000 cubic meters or less as follows. Historical earthquake-induced landslides have occurred throughout El Salvador at least a dozen times from 1857 to 2001 (Rymer and White, 1989; Baum et al., 2001). Volumes of these landslides have ranged from a few hundred to more than 10 million cubic meters, but most have had volumes of less than a few to a few tens of thousands of cubic meters. Thus, earthquake-induced landslides of small to moderate volume occur in El Salvador about once every 12 years. At San Vicente volcano, rainfall- and earthquake-triggered landslides and lahars occurred at least four times in the past 225 years, and at least three times in the past 65 years, which suggest annual probabilities of occurrence of about 1 in 60 to 1 in 20. These historical lahars reached the communities of San Vicente, Guadalupe, and Tepetitan as well as the highway between Tecoluca and Zacatecoluca (see plate 1). The volumes of these lahars are not known, but their extents suggest volumes on the order of 300,000 to 500,000 cubic meters. Although the estimated probabilities are highly generalized, we conclude that the annual probability of landslides and lahars $\leq 500,000$ cubic meters in size at San Vicente volcano is about 1 in 50 to perhaps as great as 1 in 10 .

[9] The potential extent of a regionally devastating blast pyroclastic current is estimated from the formula $\mathrm{H} / \mathrm{L}=0.09$, similar to that of the 1980 directed blast at Mount St. Helens. Although such an event would impact a very large area, events of this type have a very low frequency of occurrence. 
